\title{
The effect of cooking methods on some quality characteristics of gluteus medius
}

\author{
Veli GÖK ${ }^{1}$, Tamer UZUN², Oktay TOMAR²*, Muhammed Yusuf ÇAĞLAR², Abdullah ÇAĞLAR²
}

\begin{abstract}
In this research, the effects of cooking by convection oven and cooking by sous-vide method on the physicochemical, textural, sensorial and microbiological of gluteus medius cuts were investigated. For the sous-vide method, the meat was vacuumed sealed in special packaging material (Mylar Cook) before being stored at $+1{ }^{\circ} \mathrm{C}$ for 0,15 , and 30 days. The samples cooked with the sous-vide method had higher moisture content $(P<0.001)$ and lower cooking loss than oven roasted samples. TBARS content was affected by cooking method $(P<0.01)$ and storage time $(P<0.01)$. The 2 -thiobarbituric acid reactive substances (TBARS) values of the convection oven samples were higher than those cooked with sous-vide method. The WBSF values were affected by the cooking methods. The samples cooking with oven significantly lower shear $(P<0.0001)$ force values than those for the sous-vide method. Samples cooked by the convection oven had higher $L^{*}$ (lightness), $\mathrm{a}^{*}$ (redness), $\mathrm{b}^{*}$ (yellowness) than the cooked with sous-vide method $(P<0.0001)$. The sliced meat samples cooked by oven were given higher sensory ratings than those cooked by sous-vide except texture scores.
\end{abstract}

Keywords: sous-vide; convection oven; beef; gluteus medius; texture.

Practical Application: Roasting and sous-vide cooking are the two most common cooking methods employed in restaurants and in the catering industry. Cooking methods affect various quality characteristics of meat like as yield, tenderness, juiciness, flavor and palatability of samples. Increasing sales volume and new consumer demands in the food industry suggest that cook in bag products are growing in popularity as well as consumer satisfaction along with acceptable quality and cost.

\section{Introduction}

Meat is generally eaten after undergoing some form of heating, such as boiling, grilling, and roasting. Quality characteristics of meat and meat products are affected by meat composition and method of cooking (Bosco et al., 2001; Fabre et al., 2018). Heat treatment is one of the most common methods to achieve microbial stability and diversity of meat products. Although meat is surrounded by hot air in dry heat cooking method, such as pan frying with oil, hot liquid or steam are applied to meat in moist-heat (hydrothermal) cooking. In many applications, combinations of dry heat and moist heat treatment are implemented together (Pearson \& Gillett, 1996).

Cooking methods (grill, broil, fry, etc.) and endpoint meat temperatures are need to be closely followed as they may differ significantly for different cuts of meat. Cooking methods affect quality characteristics of meat like as yield, tenderness, juiciness, flavor and palatability by causing physical and biochemical changes in protein, carbohydrate, lipid and other minor components (Lee et al., 2014).

The last decades household consumers do not want to spent much time on food preparation and cooking. There have been great improvements in cook-chill technologies by vacuum cook-in-bag, adopted by catering services, food processing plants or household consumers (Creed \& Reeve, 1998). The reductions of oxygen prevent the deterioration caused by lipid oxidation, other chemical process, and microbial spoilage. Cook-in-bag cooking methods allow meat inside bag to be cooked in their own juice, and retain food moisture, volatile flavor components. On the other hand the intact package before and after cooking limits post-contamination risks (Creed \& Reeve, 1998).

Sous-vide cooking (SVC) is French originated cooking method which is used cooking foods under vacuum condition with controlled temperature and time (Schellekens, 1996). Sous-vide products have gained high commercial and consumer acceptance due to extended shelf life, improved consumer safety, convenience, freshness and superior taste compared to the frozen, shelf stable foods (Beauchemin, 1990). Differences are available between Sous-vide cooking and traditional cooking methods. One of them is to cook the raw food in vacuum-sealed packages which is stable to migration and heat is applied to food. The second way is to cook food in controlled heating. The advantages of vacuum-sealing are penetration ability of transfer the heat from the water or steam to the food, support to sample stability by inhibiting recontamination during storage, inhibition of lipid oxidation, prevention of cooking loss and flavor deteriorations (Stea et al., 2007). 
Increasing sales volume and new consumer demands in the food industry suggest that cook in bag products are growing in popularity as well as consumer satisfaction along with acceptable quality and cost. The purpose of this research were determine effects of cooking methods on the physochemical, textural and sensorial properties of ready to eat meat cuts.

\section{Materials and methods}

\subsection{Preparation of the beef cuts}

In this research, a comparative analysis was conducted on the difference between convention oven cooking and sous-vide cooking (SVC), by examining the effect of both cooking methods on a gluteus medius (GLM) cut of meat under different storage times. The carcasses were obtained from young Simmental (24-months old) bulls that had been slaughtered at a commercial plant in Afyonkarahisar (Turkey). The mean weight of the carcasses was $330 \mathrm{~kg}$. Round primal cuts were removed at the processing plant, packaged and transported to the laboratories. The gluteus medius muscle was selected because it is a very soft meat and very good for frying. The muscles were individually tagged and vacuum-tumbled for $45 \mathrm{~min}$ at $16 \mathrm{rpm}$ in marinade (15\% of initial muscle weight) at $4{ }^{\circ} \mathrm{C}$. The marinade contained $4 \%$ water, $8 \%$ olive oil and $3 \%$ seasoning mixture. After the meat had been subjected to vacuum tumbling, it was refrigerated at $2{ }^{\circ} \mathrm{C}$ for $12 \mathrm{~h}$. Cuts were then sliced $(1 \times 8 \times 10 \mathrm{~cm})$ and packaged in Mylar ${ }^{\circledast}$ Cook films (The base polyester film was $300 \mu \mathrm{m}$ thick and upper polyamide e film $80 \mu \mathrm{m}$ thick, oxygen permeability is $6 \mathrm{~cm}^{3} / \mathrm{m}^{2} / 24 \mathrm{~h}$ at $25^{\circ} \mathrm{C}$, and $\mathrm{CO}_{2}$ permeability is $16 \mathrm{~cm}^{3} / \mathrm{m}^{2} / 24 \mathrm{~h}$ at $25^{\circ} \mathrm{C}$. All sliced meat cuts were vacuum packaged by vacuum packaging machine (Multivac R145, Wolfertschwenden, Germany) at a pressure of 0.9 bars for $10 \mathrm{~s}$.

Three different storage times (0,15 and 30 days) and two cooking methods $\left(80^{\circ} \mathrm{C}\right.$ for sous-vide and $98^{\circ} \mathrm{C}$ for convection oven) were used for the preparation of 18 round primal cuts $(n=3$ for each batch).

\subsection{Cooking procedures}

For the convection cooking, sliced meat cuts were put in to convection oven (Combi-Master CM6, Rational GmbH, Germany) that had a digital thermocouple. The oven was preheated to $98^{\circ} \mathrm{C}$, and the sliced meat cuts were cooked to core temperature of $80{ }^{\circ} \mathrm{C}$ for $55 \mathrm{~min}$. The meat cuts were cooled to $2{ }^{\circ} \mathrm{C}$ in ice water and were stored at $1{ }^{\circ} \mathrm{C}$ after cooking. Sous-vide cooking were performed in a water bath at $80{ }^{\circ} \mathrm{C}$ for $75 \mathrm{~min}$. and the pouches were removed from the water bath and submerged in ice-cold water $\left(2^{\circ} \mathrm{C}\right)$ for $1 \mathrm{~h}$ cooking process. The packaged meat cuts were refrigerated at $1{ }^{\circ} \mathrm{C}$ for 30 days. At least 2 packages were used to read the internal product temperature by a copper constant thermocouple probed in meat piece.

\subsection{Moisture content (\%) and cooking loss (\%)}

Moisture content was determined according to Association of Official Analytical Chemists (1990) methods.

The cooking loss was calculated as Equation 1:

$\%$ Cooking loss $=[($ raw weight - cooked weight $) /$ raw weight $)] \times 100$

\subsection{TBARS content and $p H$}

The 2-thiobarbituric acid reactive substances (TBARS) test was used to determine of the lipid oxidation of samples throughout the storage period. Based on the method defined by Tarladgis et al. (1960) as modified by Shahidi et al. (1985) TBARS analysis was performed by uv- spectrometer at $530 \mathrm{~nm}$ (Shimadzu, Japan).

$10 \mathrm{gr}$ of blended beef sample and $90 \mathrm{~mL}$ distilled water were homogenized for 30 seconds. $\mathrm{pH}$ values were measured with glass electrode attached to a Hanna pH meter (Model 2210, Hanna Instruments, USA).

\subsection{Warner-Bratzler Shear Force (WBSF)}

TA XT-2i Texture Analyser (StableMicro Systems Ltd., Surrey, UK) was used to perform shear force analysis (SF). Shear force (SF) on cooked samples $(3 \mathrm{~cm}$ length $\times 1 \mathrm{~cm}$ width $\times 1 \mathrm{~cm}$ thickness) was determined using a Warner-Bratzler blade, shearing the specimen perpendicularly to the muscle fibers at a constant speed of $1 \mathrm{~mm} / \mathrm{s}$ and then pushing through the slot. The maximum force $(\mathrm{kg})$ required to shear the sample was measured.

\subsection{Instrumental color measurement}

Instrumental color measurements of cooked sliced beef surfaces were taken after opening the vacuum packages and wiped free of sauce with paper towel and then evaluated for color using a spectro-colorimeter (Minolta CR 400, Japan).Before the each measurement, the apparatus of colorimeter was fixed against a white plate. Color parameters such as $\mathrm{L}^{\star}$ (lightness), $\mathrm{a}^{\star}$ (redness) and $b^{\star}$ (yellowness) values were measured on surface of cooked meat for 6 times for each sample after 30 minutes of bloom time.

\subsection{Microbiological analyses}

Ten $g$ sliced beef samples were collected aseptically and $90 \mathrm{~mL}$ peptone water (BPW, Oxoid Ltd., UK) was added and homogenized for 3 minutes in Stomacher Lab-Blender 400 (London, UK). Plate count agar (PCA Oxoid CM463, Oxoid) was used to determine the total viable counts (mesophilic aerobic bacteria) and Psychotropic bacteria by incubating the plates for 24-48 hour at $37^{\circ} \mathrm{C}$ and 10 days at $7{ }^{\circ} \mathrm{C}$, respectively. Moreover, coliform bacteria was counted with after the incubataion at $35^{\circ} \mathrm{C}$ for $24 \mathrm{~h}$.

\subsection{Sensory analysis}

Sensorial panel was carried out by trained 10 panelists consisting of students and academicians from the Food Engineering Department of Afyon Kocatepe University, Turkey. Beef samples cut into $1.0 \times 2.0 \times 1.54 \mathrm{~cm}$ pieces were evaluated by panelists at room temperature and deionized rinse water and unsalted bread pieces were consumed after the each evaluation. Trained panelists $(n=10)$ evaluated palatability attributes on a five-point scale for taste, texture, juiciness, odor, color, and overall acceptability.

\subsection{Statistical analysis}

The factorial structure $(2 \times 3)$ was applied as the design of the study whereas cooking methods (sous-vide and oven) and storage time ( 0,15 and 30 days) were the factors. SPSS statistical 
package program (SPSS Inc., Chicago, IL) was run for two-way ANOVA. Lsmeans values were generated and corresponding Tukey's HSD test. The treatment structure was completely randomized with 3 replications (muscles from three different carcasses).

\section{Results and discussion}

\subsection{Moisture content, cooking loss}

Cooking methods and storage time affected $(P<0.0001)$ the moisture contents of cooked meat sliced (Table 1). Moisture content significantly $(\mathrm{P}<0.0001)$ increased with storage period. The samples cooked with the sous-vide method had higher moisture content $(P<0.001)$. Cooking rate differences between sous-vide and convection oven cooking may be responsible for some of the changes observed in moisture content (Table 2). Similarly, Roldán et al. (2015) reported that sous-vide cooked lamb had higher moisture content than oven roasted lamb. On the other hand Sánchez del Pulgar et al. (2012) reported that cooking methods did not directly affect the moisture content and weight loses of meat.

While the $\mathrm{pH}$ value was not affected by cooking method $(\mathrm{P}>0.05)$, it was affected by storage time $(P<0.05)$. There was no significant relationship $(\mathrm{P}>0.05)$ found between cooking method and storage time interaction on the $\mathrm{pH}$ values.

A strong $(P<0.01)$ cooking methods $\times$ storage time interaction effect was found for cooking loss (Table 1) (Equation 1). As a general trend a lower cooking loss with sous-vide cooking than convection oven cooking was observed irrespective of storage time (Figure 1). Cooking loss of SVC samples that reached the lower core temperatures that lead higher moisture

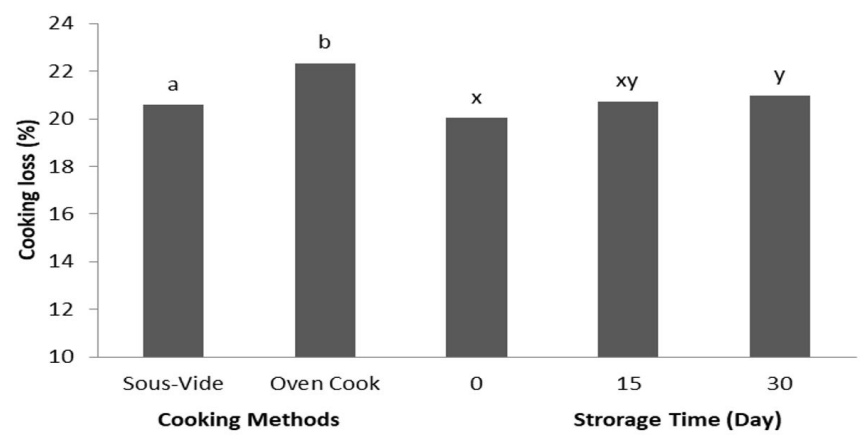

Figure 1. Effect of cooking method and storage time on cooking loss. Means within a factor with different letters are significantly different $(\mathrm{p}<0.05)$.

Table 1. Probability values of physicochemical analyses (p-values) for source of variation.

\begin{tabular}{lcccc}
\hline \multicolumn{1}{c}{ Source of variation } & Moisture & Cooking Loss & pH & TBARS \\
\hline Cooking method & $<.0001$ & $<.0001$ & 0.3011 & 0.0083 \\
Storage time & 0.0069 & 0.0015 & 0.0111 & 0.0011 \\
Cooking method $\times$ storage time & 0.1287 & 0.0064 & 0.5692 & 0.0001 \\
\hline
\end{tabular}

TBARS = 2-thiobarbituric acid reactive substances; WBSF = Warner-Bratzler Shear Force.

Table 2. The effects of cooking method, storage time, cooking method $\times$ storage time interaction on moisture $(\%)$, color values $\left(\mathrm{L}^{\star}, \mathrm{a}^{\star}, \mathrm{b}^{*}\right)$, TBA (mg malonaldehyde/kg), $\mathrm{pH}$, microbiological counts (log cfu/g) cooked sliced meat.

\begin{tabular}{|c|c|c|c|c|c|c|c|c|c|}
\hline Source of variation & Moisture & $\mathrm{pH}$ & TBA & $\mathrm{L}^{*}$ & $a^{*}$ & $\mathrm{~b}^{*}$ & $\mathrm{MAB}$ & Coliforms & $\mathrm{PB}$ \\
\hline \multicolumn{10}{|l|}{ Cooking Method } \\
\hline Sous-vide & $67.93^{\mathrm{b}}$ & 5.84 & $0.76^{\mathrm{b}}$ & $48.64^{\mathrm{b}}$ & $9.31^{\mathrm{b}}$ & $12.13^{\mathrm{b}}$ & $3.83^{\mathrm{a}}$ & $3.78^{\mathrm{a}}$ & $3.27^{\mathrm{b}}$ \\
\hline Oven & $67.53^{\mathrm{a}}$ & 5.85 & $0.89^{\mathrm{a}}$ & $52.19^{\mathrm{a}}$ & $9.42^{\mathrm{a}}$ & $12.32^{\mathrm{a}}$ & $3.28^{\mathrm{b}}$ & $3.52^{\mathrm{b}}$ & $3.46^{\mathrm{a}}$ \\
\hline$P$ value & $<0.0001$ & 0.3011 & 0.0083 & $<0.0001$ & $<0.0001$ & $<0.0001$ & 0.0007 & 0.0005 & 0.0013 \\
\hline \multicolumn{10}{|l|}{ Storage Time (days) } \\
\hline 0 & $67.80^{\mathrm{b}}$ & $5.81^{\mathrm{b}}$ & $0.59^{\mathrm{a}}$ & $51.01^{\mathrm{a}}$ & $10.07^{\mathrm{a}}$ & $11.95^{\mathrm{b}}$ & $3.28^{\mathrm{c}}$ & $2.19^{c}$ & $2.14^{\mathrm{c}}$ \\
\hline 15 & $67.90^{\mathrm{b}}$ & $5.83^{\mathrm{b}}$ & $0.78^{\mathrm{ab}}$ & $46.83^{c}$ & $9.52^{\mathrm{b}}$ & $13.05^{\mathrm{a}}$ & $3.56^{\mathrm{b}}$ & $3.53^{\mathrm{b}}$ & $4.34^{\mathrm{b}}$ \\
\hline 30 & $68.1^{\mathrm{a}}$ & $5.89^{\mathrm{a}}$ & $0.91^{\mathrm{b}}$ & $48.09^{\mathrm{b}}$ & $8.95^{\mathrm{c}}$ & $11.39^{c}$ & $4.33^{\mathrm{a}}$ & $4.38^{\mathrm{a}}$ & $4.52^{\mathrm{a}}$ \\
\hline$P$ value & 0.0069 & 0.0111 & 0.0011 & $<0.0001$ & $<0.0001$ & $<0.0001$ & $<0.0001$ & $<0.0001$ & $<0.0001$ \\
\hline \multicolumn{10}{|c|}{ Cooking method $\times$ storage time } \\
\hline SV X 0 & 67.80 & 5.81 & 0.59 & $51.01^{\mathrm{c}}$ & $10.07^{\mathrm{b}}$ & $11.95^{\mathrm{c}}$ & $3.48^{\mathrm{c}}$ & 2.20 & $2.00^{\mathrm{e}}$ \\
\hline SV X 15 & 67.90 & 5.83 & 0.78 & $46.83^{e}$ & $9.52^{\mathrm{d}}$ & $13.05^{\mathrm{a}}$ & $3.75^{\mathrm{b}}$ & 4.66 & $3.62^{\mathrm{c}}$ \\
\hline SV X 30 & 68.10 & 5.89 & 0.91 & $48.09^{\mathrm{d}}$ & $8.35^{\mathrm{e}}$ & $11.39^{\mathrm{d}}$ & $4.26^{\mathrm{a}}$ & 4.48 & $4.20^{\mathrm{b}}$ \\
\hline OC X 0 & 67.50 & 5.83 & 0.74 & $54.23^{\mathrm{b}}$ & $10.63^{\mathrm{a}}$ & $12.97^{\mathrm{a}}$ & $3.08^{\mathrm{d}}$ & 2.02 & $2.38^{\mathrm{d}}$ \\
\hline OC X 15 & 67.50 & 5.85 & 0.92 & $55.95^{\mathrm{a}}$ & $7.88^{\mathrm{f}}$ & $12.53^{\mathrm{b}}$ & $3.38^{\mathrm{c}}$ & 4.38 & $3.45^{\mathrm{c}}$ \\
\hline OC X 30 & 67.60 & 5.88 & 1.01 & $46.39^{\mathrm{f}}$ & $9.76^{\mathrm{c}}$ & $11.46^{\mathrm{d}}$ & $4.40^{\mathrm{a}}$ & 4.20 & $4.56^{\mathrm{a}}$ \\
\hline $\mathrm{P}$ value & 0.1287 & 0.5692 & 0.8194 & $<.0001$ & $<.0001$ & $<.0001$ & 0.018 & 0.001 & 0.0009 \\
\hline
\end{tabular}

$\mathrm{TBA}=2$-thiobarbituric acid reactive substances; $\mathrm{MAB}=$ Mesophilic aerobic bacteria; $\mathrm{PB}=$ psychrophilic bacteria. Means within a column with different letters are significantly different $(p<0.05)$. 
content was lower than the oven roasted samples Similarly García-Segovia et al. (2007) and Roldán et al. (2015) reported lower cooking loss with sous-vide cooking as compared other cooking methods. Cooking methods and conditions affect the cooking loss during the process (Stea et al., 2007).

\section{$3.2 p H$ and TBA}

Measures of TBARS were used to assess degree of lipid oxidation. Lipid oxidation can cause rancidity and warmed-over flavor (WOF) in meat products. TBARS content was affected by cooking method $(P<0.01)$ and storage time $(P<0.01)$ (Table 1$)$. The TBARS values of the convection oven samples were higher than those cooked with sous-vide method $(P<0.01)$ (Table 2$)$. This is in agreement with Weber et al. (2008) who found more oxidation samples than in roasted ones.

The sample cooked in the oven had the highest TBA value (1.01 mg malonaldehyde/kg) after 30 days. The rancidity and WOF may be occurred by lipid oxidation that may result undesired flavors in meat products at TBARS value below a threshold about $1 \mathrm{mg} / \mathrm{kg}$ meat (Jahan et al., 2004). Moreover, lipid oxidation increases with higher cooking temperatures and cooking times according to Sánchez del Pulgar et al. (2012). Researcher reported lower TBARS in pork cheeks samples cooked at higher temperatures and for longer times. Bosco et al. (2001) indicated that lipid oxidation may be affected by thermal treatments including cooking method, rate and final temperature and meat composition consisting of various components and portions such as lipids or antioxidants. The SVC could have helped to minimize the amount of oxidation in the cooked meat.

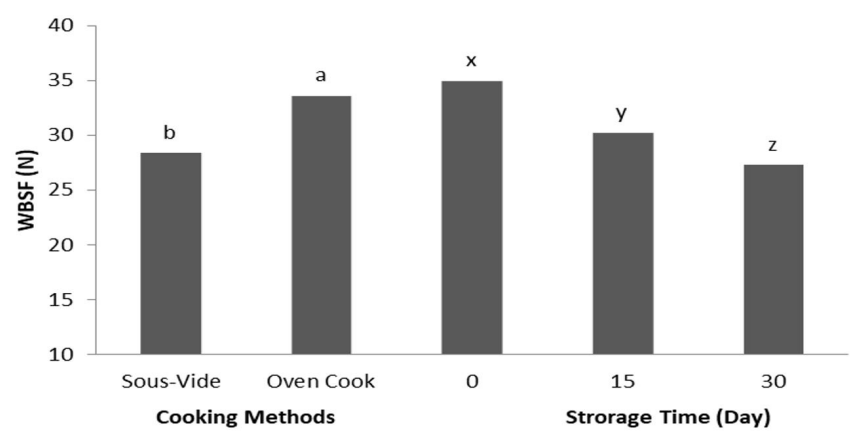

Figure 2. Effect of cooking method and storage time on WBSF (N). Means within a factor with different letters are significantly different $(P<0.05)$.

\subsection{Warner-Bratzler Shear Force (WBSF)}

Cooking method $(P<0.0001)$ and storage time $(P<0.01)$ affected the WBSF value as shown in Table 1, but in terms of the relationship between cooking method and storage time $(P>0.05)$, this value was determined to be not significantly affected. Moreover, Figure 2 shows the force required to shear samples of cooked meat with Warner-Bratzler blade.

The increased of the shear forces of the cooked meat samples indicated an increasing in sample hardness and decreasing in tenderness. Shear force on raw meat is mainly showing background or collagen toughness, whereas shear force on cooked meat may be considered a measure of myofibrillar toughness (De Smet et al., 1998). The WBSF values were significantly affected by the cooking methods. The samples cooking with oven significantly lower shear $(P<0.0001)$ force values than those for the sous-vide method. These results are similar to previous studies. García-Segovia et al. (2007) that has found cooking M. Pectoralis muscles with sous-vide more tender than cooking with atmospheric pressure. Fabre et al. (2018) concluded that Sous-vide cooking increased tenderness of longissimus thoracis, semitendinosus, semimembranosus and Biceps femoris muscles. Structure of meat components may be changed during heat treatment that may lead toughness of meat samples. In the studies driven by Palka \& Daun (1999) and Palka (2003), Semitendinosus muscle beef was cooked at various temperatures and texture of the samples were analyzed where the hardness of the samples cooked at $70^{\circ} \mathrm{C}$ and $80^{\circ} \mathrm{C}$ were higher than the beef samples cooked at $60^{\circ} \mathrm{C}$.

\subsection{Color values}

$\mathrm{L}^{*}, \mathrm{a}^{*}$, or $\mathrm{b}^{*}$ values were affected by cooking methods and storage time and interaction between cooking method and storage time on colour parameters is shown in Table 3 (p $<0.0001$ ). $\mathrm{L}^{*}$ values of the beef samples cooked at oven was higher than the ones cooked at SVC $(p<0.0001)$. Consumers may prefer lighter colour on meat products that can be expressed with high $\mathrm{L}^{*}$ values. Samples cooked by the convection oven, brighter (higher $\mathrm{L}^{*}$ ), more red (higher $\mathrm{a}^{*}$ ), and more yellow (higher $\mathrm{b}^{*}$ ) than the cooked with sous-vide method $(\mathrm{P}<0.0001)$. Similarly, Roldán et al. (2015) reported that the color of lamb loins cutting surfaces was brighter and redder for cooked in oven than samples cooked with sous-vide method. Browning reaction may occur by the time that may change the brightness in meat products as expressed with lower $L^{\star}$ values (Gök et al., 2008). The $L^{*}$ values of the meat samples were found to decrease $(\mathrm{P}<0.0001)$ with increased storage time (Table 2).

Geileskey et al. (1998) stated that, denaturation of myoglobin that is the color pigment on bright red meat starts at $60^{\circ} \mathrm{C}$. Redness

Table 3. Probability values of microbiological analyses ( $\mathrm{p}$-values) for source of variation.

\begin{tabular}{|c|c|c|c|c|c|c|}
\hline Source of variation & $\mathrm{L}^{*}$ & $a^{*}$ & $b^{*}$ & $\mathrm{MAB}$ & Coliforms & $\mathrm{PB}$ \\
\hline Cooking method & $<.0001$ & 0.0171 & 0.0013 & 0.0007 & 0.0005 & 0.0013 \\
\hline Storage time & $<.0001$ & $<.0001$ & $<.0001$ & $<.0001$ & $<.0001$ & $<.0001$ \\
\hline Cooking method $\times$ storage time & $<.0001$ & $<.0001$ & $<.0001$ & 0.0009 & 0.001 & 0.0009 \\
\hline
\end{tabular}

$\mathrm{MAB}=$ Mesophilic aerobic bacteria; $\mathrm{PB}=$ psychrophilic bacteria. 
of beef samples cooked by convection oven method was higher than the SVC samples $(\mathrm{P}<0.0001)$. Moreover, storage for 15 days resulted in lower $\mathrm{a}^{*}$ as shown in Table 2 . The yellowness values were also significantly higher $(\mathrm{p}<0.05)$ for the samples cooked at oven than for steaks cooked at the SVC. Roldán et al. (2013) indicated that the formation of metmyoglobin and denaturation of this molecule by heat treatment lead brown color that is expressed by increased $\mathrm{b}^{*}$ values.

As shown in Table 3, there was a significant cooking method $\times$ storage time interaction for mesophilic aerobic bacteria $(\mathrm{P}<0.001)$, coliforms $(\mathrm{P}<0.001)$, or $(\mathrm{P}<0.0001)$, coliforms $(\mathrm{P}<0.0001)$, or psychrophilic bacteria $(\mathrm{P}<0.001)$.

\subsection{Microbial counts}

The convection oven method was found to reduce mesophilic aerobic bacteria count $(\mathrm{P}<0.001)$ and coliforms count $(\mathrm{P}<0.001)$ more than the sous-vide method; however, the sous-vide method was observed to reduce the psychrophilic bacteria more effectively than the convection oven method. Microbial count was found to increase with the storage period ( $\mathrm{P}<0.0001)$. Roldán et al. (2013) cooked lamb loins using the SVC and determined that for all of the microbial groups, except to mesophilic bacteria, which ranged from 0.9-2.7 log cfu/g, the counts were not detectable or were lower than $\log 1 \mathrm{cfu} / \mathrm{g}$. It is concluded that SVC may hold the microbial stability of meat products during the cold storage period in long term that is required by the catering industry. This finding is in agreement with other studies conducted on meat-based meals cooked using the sous-vide method (Wang et al., 2004). The mesophilic aerobic bacteria count in the cooked products after 30 days storage at $1{ }^{\circ} \mathrm{C}$ were in the range $4.26-4.40 \mathrm{log} \mathrm{cfu} / \mathrm{g}$ (Table 2) that all samples counts under the maximum specification in Turkish Food Codex (Turkey, 2011).

\subsection{Sensory analysis}

The effects of cooking methods and the storage time on different sensory attributes of cooked sliced meat are shown in Table 4. Cooking methods affected the color $(P<0.01)$, taste $(P<0.05)$ and acceptability $(P<0.05)$ scores. All sensorial scores declined with the lowest scores observed on day 30 (Table 5).

Meat sliced cooked by oven had higher sensory ratings than those cooked by SVC except texture scores $(\mathrm{P}<0.05)$. Similarly Roldán et al. (2015) reported sous-vide preparation of lamb loins led to a less bright color, a less chewy, less juicy and less intense flavor as compare to lamb loins cooked with oven.

The oven cooked samples had higher color scores than sous-vided cooked samples. The color measurement by instruments of surface of cooked meat is presented in Table 2. The cooking of meat slices by oven led to higher juiciness scores. However, Bejerholm \& Aaslyng (2003) reported that lower cooking loss resulting in a juicier meat product. In our study the oven cooked

Table 4. Probability values of sensory analyses ( $\mathrm{p}$-values) for source of variation.

\begin{tabular}{lllcccr}
\hline \multicolumn{1}{c}{ Source of variation } & Color & Taste & Texture & Juiciness & Odor & Acceptability \\
\hline Cooking method & 0.047 & 0.044 & 0.7637 & 0.025 & 0.443 & 0.046 \\
Storage time & 0.004 & 0.002 & 0.08 & 0.035 & 0.039 & 0.001 \\
Cooking method $\times$ storage time & 0.125 & 0.9610 & 0.2630 & 0.351 & 0.773 & 0.065 \\
\hline
\end{tabular}

Table 5. The effects of cooking method, storage time, cooking method $\times$ storage time interaction on sensory properties of cooked meat.

\begin{tabular}{|c|c|c|c|c|c|c|}
\hline Source of variation & Color & Taste & Texture & Juiciness & Odor & Acceptability \\
\hline \multicolumn{7}{|l|}{ Cooking method } \\
\hline Sous-vide & $3.39^{\mathrm{b}}$ & $3.79^{\mathrm{b}}$ & 3.47 & $3.72^{\mathrm{b}}$ & 3.79 & $3.51^{\mathrm{b}}$ \\
\hline Oven & $3.53^{\mathrm{a}}$ & $3.92^{\mathrm{a}}$ & 3.44 & $3.85^{\mathrm{a}}$ & 3.90 & $3.81^{\mathrm{a}}$ \\
\hline P value & 0.047 & 0.044 & 0.7637 & 0.025 & 0.443 & 0.046 \\
\hline \multicolumn{7}{|l|}{ Storage Time (days) } \\
\hline 0 & $3.61^{\mathrm{a}}$ & $3.96^{\mathrm{a}}$ & $3.69^{\mathrm{a}}$ & $3.59^{\mathrm{a}}$ & $3.94^{\mathrm{a}}$ & $3.78^{\mathrm{a}}$ \\
\hline 15 & $3.29^{\mathrm{b}}$ & $3.81^{\mathrm{a}}$ & $3.33^{\mathrm{b}}$ & $3.56^{\mathrm{a}}$ & $3.79^{\mathrm{ab}}$ & $3.68^{\mathrm{b}}$ \\
\hline 30 & $3.24^{\mathrm{b}}$ & $3.31^{\mathrm{b}}$ & $3.12^{\mathrm{b}}$ & $3.17^{\mathrm{b}}$ & $3.57^{\mathrm{b}}$ & $3.52^{\mathrm{c}}$ \\
\hline P value & 0.004 & 0.002 & 0.08 & 0.035 & 0.039 & 0.001 \\
\hline \multicolumn{7}{|c|}{ Cooking method $\times$ storage time } \\
\hline SV X 0 & 3.60 & 3.90 & 3.82 & 3.78 & 3.86 & 3.61 \\
\hline SV X 15 & 3.23 & 3.75 & 3.31 & 3.67 & 3.75 & 3.51 \\
\hline SV X 30 & 3.24 & 3.73 & 3.29 & 3.70 & 3.75 & 3.43 \\
\hline OC X 0 & 3.75 & 4.02 & 3.57 & 3.98 & 4.01 & 3.94 \\
\hline OC X 15 & 3.53 & 3.86 & 3.36 & 3.81 & 3.83 & 3.86 \\
\hline OC X 30 & 3.32 & 3.87 & 3.39 & 3.77 & 3.85 & 3.62 \\
\hline P value & 0.125 & 0.9610 & 0.2630 & 0.351 & 0.773 & 0.065 \\
\hline
\end{tabular}

Means within a column with different letters are significantly different $(P<0.05)$. 
had higher cooking loss (Figure 1) but the panelist had scored higher juiciness ratings. This difference on juiciness of the samples can be attributed to the difficulties of semi-professional panelists' evaluation.

\section{Conclusion}

Microbial stability of meat products can be carried out by SVC in long time refrigeration in food industry. Sous-vide cooking of gluteus medius resulted in significantly lower cooking loss and higher tenderness compared to oven cooking samples. Oven cooking showed the highest lipid oxidation and color values. Microbial count of the samples were affected the cooking methods and storage time. All samples microbial counts had lower than Food codex limit. The convection oven method inhibited mesophilic aerobic bacteria more effectively than the sous-vide method. Generally, oven cooking resulted in better sensory attributes than sous-vide cooking. In the future works, effect of cooking methods on quality and sensorial parameters on various muscles should be investigated.

\section{References}

Association of Official Analytical Chemists - AOAC. (1990). Official methods of analysis (15th ed.). Washington: AOAC.

Beauchemin, M. (1990). Sous-vide technology. Q.C.R \& D. Research Bulletin, 17(1), 1-11.

Bejerholm, C., \& Aaslyng, M. D. (2003). The influence of cooking technique and core temperature on results of a sensory analysis of pork: depending on the raw meat quality. Food Quality and Preference, 15(1), 19-30. http://dx.doi.org/10.1016/S0950-3293(03)00018-1.

Bosco, A. D., Castellini, C., \& Bernardini, M. (2001). Nutritional quality of rabbit meat as affected by cooking procedure and dietary vitamin E. Journal of Food Science, 66(7), 1047-1051. http://dx.doi. org/10.1111/j.1365-2621.2001.tb08233.x.

Creed, P. G., \& Reeve, W. (1998). Principles and applications of sous vide processed foods. In S. Ghazala (Ed.), Sous vide and cook-chill processing for the food industry. Gaithersburg: Aspen.

De Smet, S., Claeys, E., Buysse, G., Lenaerts, C., \& Demeyer, D. (1998). Tenderness measurements in four muscles of Belgian blue normal and double-muscled bulls. In Proceedings of the 44th International Congress of Meat Science and Technology (pp. 288-289). Barcelona: IcoMST.

Fabre, R., Dalzotto, G., Perlo, F., Bonato, P., Teira, G., \& Tisocco, O. (2018). Cooking method effect on Warner-Bratzler shear force of different beef muscles. Meat Science, 138, 10-14. http://dx.doi.org/10.1016/j. meatsci.2017.12.005. PMid:29289713.

García-Segovia, P., Andrés-Bello, A., \& Martínez-Monzó, J. (2007). Effect of cooking method on mechanical properties, color and structure of beef muscle (M. pectoralis). Journal of Food Engineering, 80(3), 813821. http://dx.doi.org/10.1016/j.jfoodeng.2006.07.010.

Geileskey, A., King, R. D., Corte, D., Pinto, P., \& Ledward, D. A. (1998). The kinetics of cooked meat haemoprotein formation in meat and model systems. Meat Science, 48(3-4), 189-199. http://dx.doi.org/10.1016/ S0309-1740(97)00089-2. PMid:22063067.

Gök, V., Obuz, E., \& Akkaya, L. (2008). Effects of packaging method and storage time on the chemical, microbiological, and sensory properties of Turkish pastirma: a dry cured beef product. Meat Science, 80(2), 335344. http://dx.doi.org/10.1016/j.meatsci.2007.12.017. PMid:22063338.

Jahan, K., Paterson, A., \& Spickett, C. M. (2004). Fatty acid composition, antioxidantsand lipid oxidation in chicken breasts from different production regimes. International Journal of Food Science \& Technology, 39(4), 443-453. http://dx.doi.org/10.1111/j.1365-2621.2004.00799.x.
Lee, Y., Xiong, R., Chang, Y. H., Owens, C. M., \& Meullenet, J. F. (2014). Effects of cooking methods on textural properties and water-holding capacity of broiler breast meat deboned at various postmortem times. Journal of Texture Studies, 45(5), 377-386. http://dx.doi.org/10.1111/ jtxs. 12088 .

Palka, K. (2003). The influence of post-mortem ageing and roasting on the microstructure, texture and collagen solubility of bovine semitendinosus muscle. Meat Science, 64(2), 191-198. http://dx.doi. org/10.1016/S0309-1740(02)00179-1. PMid:22062866.

Palka, K., \& Daun, H. (1999). Changes in texture, cooking losses, and myofibrillar structure of bovine $M$. semitendinosus during heating. Meat Science, 51(3), 237-243. http://dx.doi.org/10.1016/S03091740(98)00119-3. PMid:22061858.

Pearson, A. M., \& Gillett, T. A. (1996). Meat cookery and cooked meat products. In A. M. Pearson \& T. A. Gillett, Processed meats. Boston: Springer. http://dx.doi.org/10.1007/978-1-4615-7685-3_5.

Roldán, M., Antequera, T., Martin, A., Mayoral, A. I., \& Ruiz, J. (2013). Effect of different temperature-time combinations on physicochemical, microbiological, textural and structural features of sous-vide cooked lamb loins. Meat Science, 93(3), 572-578. http://dx.doi.org/10.1016/j. meatsci.2012.11.014. PMid:23273466.

Roldán, M., Loebner, J., Degen, J., Henle, T., Antequera, T., \& Ruiz-Carrascal, J. (2015). Advanced glycation end products, physico-chemical and sensory characteristics of cooked lamb loins affected by cooking method and addition of flavour precursors. Food Chemistry, 168, 487-495. http://dx.doi.org/10.1016/j.foodchem.2014.07.100. PMid:25172739.

Sánchez del Pulgar, J., Gázquez, A., \& Ruiz-Carrascal, J. (2012). Physicochemical, textural and structural characteristics of sous-vide cooked pork cheeks as affected by vacuum, cooking temperature, and cooking time. Meat Science, 90(3), 828-835. http://dx.doi.org/10.1016/j. meatsci.2011.11.024. PMid:22154568.

Schellekens, M. (1996). New research issues in sous-vide cooking. Trends in Food Science \& Technology, 7(8), 256-262. http://dx.doi. org/10.1016/0924-2244(96)10027-3.

Shahidi, F., Rubin, L. J., Diosady, L. L., \& Wood, D. F. (1985). Effect of sulfanilamide on the TBA values of cured meats. Journal of Food Science, 50(1), 274-275. http://dx.doi.org/10.1111/j.1365-2621.1985.tb13332.x.

Stea, T. H., Johansson, M., Jägerstad, M., \& Frølich, W. (2007). Retention of folates in cooked, stored and reheated peas, broccoli and potatoes for use in modern large-scale service systems. Food Chemistry, 101(3), 1095-1107. http://dx.doi.org/10.1016/j.foodchem.2006.03.009.

Tarladgis, B. G., Watts, B. M., Younathan, M. T., \& Dugan, L. R. Jr. (1960). A distillation method for the quantitative determination of malonaldehyde in rancid foods. Journal of the American Oil Chemists' Society, 37(1), 44-48. http://dx.doi.org/10.1007/BF02630824.

Turkey. (2011, December 29). Regulation on Turkish Food Codex microbiological criteria. Law of Authorization: 5996. Official Gazette of Publication.

Wang, S. H., Chang, M. H., \& Chen, T. C. (2004). Shelf-life and microbiological profiler of chicken wing products following sous vide treatment. International Journal of Poultry Science, 3(5), 326-332. http://dx.doi.org/10.3923/ijps.2004.326.332.

Weber, J., Bochi, V. C., Ribeiro, C. P., Victório, A. M., \& Emanuelli, T. (2008). Effect of different cooking methods on the oxidation, proximate and fatty acid composition of silver catfish (Rhamdia quelen) fillets. Food Chemistry, 106(1), 140-146. http://dx.doi.org/10.1016/j. foodchem.2007.05.052. 